\title{
鋼板側から元たほうろうの密着性
}

$$
\text { 吉田誠* }
$$

\section{The Adherence of Porcelain Enamel to Steel Sheet}

Makoto YOSHIDA*

\section{1.まえがき}

現在, ほうろうは台所用品・衛生用品・化学装置・浴 槽・建築材料など多方面に用いられているが，乙れはほ うろう被覆が耐食性・耐薬品性・耐污染性・耐熱性・耐 摩耗性・豊富な色彩など数々の優れた特性を備えている ためである。

しかし，ほうろうは鋼と親和力の小さいガラス質のゆ う薬を被覆するため，鋼板に対する制約屯多く，ほうろ う前処理む他の表面処理法に比べて複雑である。また, $800^{\circ} \mathrm{C}$ 以上の高温で焼成されるため金属めっきや塗装 などに見られない爪とび，泡，焼成督，密着不良などの 欠陷を生じやすい。中であほうろう密着性はほうろう被 覆の根本問題であり, 古くからその機構も含めて多くの 検討がなされており1)41)，技術的に一応完成されたあの と一般には考えられているようである。

しかしながら，ほうろう密着要因は因子が多いばかり でなく複雑にからみ合うことから全因子を適正条件範囲 に管理することは難しく，ほうろうメーカーにおいてす しばしば密着不良問題を起こしているのが現状である。 また，近年ほうろう用鋼板は造塊鋼（リムド鋼）から連続 鋳造鋼(キルド鋼)へ移行しているが, リムド鋼に適用さ れる鋼板製造条件や前処理条件範囲がそのままキルド鋼 に適用できない点も指摘されている5)。以上の理由から， 改めてほうろうと鋼板の密着要因について整理し, 再考 するととは意義あることと思える。

ほうろう密着性の要因は大別すると「鋼板」,「前処理」, 「ゆう薬」,「焼成」の 4 つに分けられるが，本解説では鋼 板製造側の立場として「鋼板」と「前処理」について述 べるとととする。

なお，本文の前にほうろう密着機構について従来から の考え方を整理しておく。

* 新日本製鉄(株)八幡技術研究部（干 805 福岡県北九州市八幡東区枝 光 1-1-1)

Yawata Technical Research Div, Nippon Steel Corp. (1-1, Edamitsu 1-chome, Yawata-Higashi-ku, Kitakyushu-shi, Fukuoka 805)

\section{2.ほうろうの密着機構}

ほうろう密着機構に関しては古くから諸説が提唱され ており，ほうろう焼成中に生成される $\mathrm{FeO}$ を媒体とする 化学的結合と前処理によって生じた鋼板表面粗さやほう ろう焼成中に電気化学的腐食(Galvanic Corrosion)な どによって形成される微細な凹凸による機械的結合に大 別される。

\section{1 機械的結合説}

機械的結合説は金属とほうろう層が相互に入り組んだ 界面を形成し，そのくさび勃果によって接着強度が得ら れるとの説に立っている。ほうろう焼成過程で界面に微 細な凹凸を形成させる電気化学的腐食作用はA. Dietzel ${ }^{6)}$ が最初に提唱したもので, 下ゆう薬に加えられるCoOお よび $\mathrm{NiO}$ の働きを説明している。

すなわち，鋼板に融けたほうろう質が接触すると，ま す溶融ほうろう質層から金属Coまたは Ni が鋼板表面に 析出し, 鋼板をアノード, 析出 Co をカソードとする局 部電池が図1亿示すように形成される。

鋼板アノードはほうろう質融体中に陽極的に融け出し て孔を生じ，Coカソードでは拡散してくる $\mathrm{O}_{2}$ と結合し て CoOとなって融解し, 生じた $\mathrm{Co}^{2+}$ が綠り返し陰極的に 析出する反応が行われるとしている。

下ゆう薬中の $\mathrm{CoO} や \mathrm{NiO}$ と同様の働きをするあのと して，鋼中 $\mathrm{Cu}$ などを含んだ酸洗残查物(スマット), $\mathrm{Ni}$ 浸せき妈理によって析出した Ni 金属などが挙げられる。 その他，機械的結合作用を生じるものとして酸洗前処 理, ブラスト処理, 電解エッチングによる表面粗化もほ

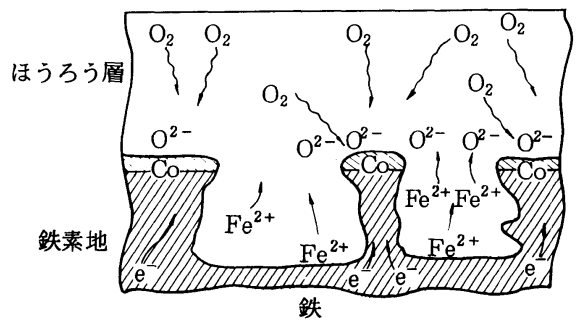

図 $1 \mathrm{CoO}$ を含むほうろう層による電気化学腐食作用 ${ }^{6)}$ 


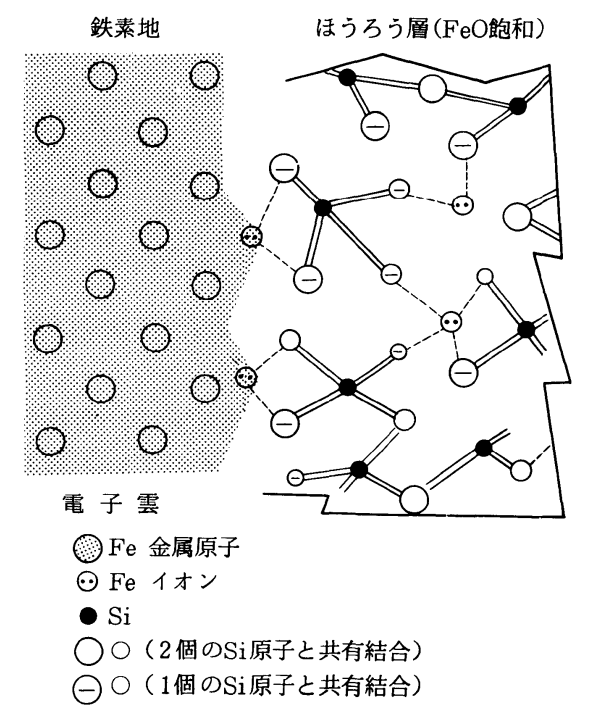

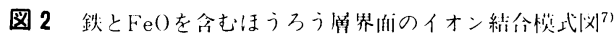

うろう密着性の向上に寄与するあのと考えられており, 比較的容認されやすい説である。

\section{2 化学的結合説}

一方, 化学的結合説は, ほうろうと鋼板の界面を調べ ていくと機械的かみ合いだけでは説明できない場合があ るとして提案された説である。

B. W. King ${ }^{7)}$ やJ. A. Pask ${ }^{8)}$ らによると図 2 の模式図 に示すように， $\mathrm{FeO}$ を飽和したほうろう層中では電荷の バランスを維持するために全てのO原子が $\mathrm{Si}$ 原子と共有 結合しているのではなく, 複数のO原子が 1 個の Si 原子 と結合し負電荷を持っている。乙れらのO-は鋼板表面の $\mathrm{Fe}^{2+}$ とイオン結合しているとする説である。

しかし，鋼板とほうろう層界面におけるかみ合い構造 が全く存在しないでほうろう被覆が鋼板とよく接着する 事例は発表されておらず，ほうろう密着は機械的結合が 主因で化学的結合は補助的な役割を果たすすのであると するのが現在では有力である。

\section{3. 鋼中微㙉元秦とほうろう密着性}

ほうろう密着性を得るためには, 酸洗前処理において 一定量以上の酸洗減量が必要である。従って, 前処理の 能率面から酸洗速度の大きい材料が好ましいとされ, 酸 洗減量におよぼす鋼中微量元素の影響が検討されてい $ろ^{21,3)}$ 。図 3 によると酸洗速度を増大させる元素は $\mathrm{P}$, $\mathrm{S}, \mathrm{Cr}, \mathrm{Si}$ である。逆に酸洗速度を低下させる元素は $\mathrm{Cu}, \mathrm{Sb}, \mathrm{Mo}, \mathrm{Sn}$ である。しかし，注意しなければな らないてとは酸洗速度の大きい鋼板がかならずしも密着 性が良いとは限らず, 酸洗速度の大きい脱炭りムド鋼板 が良好なほうろう密着性を与える $\mathrm{Ni}$ 浸せき処理条件範

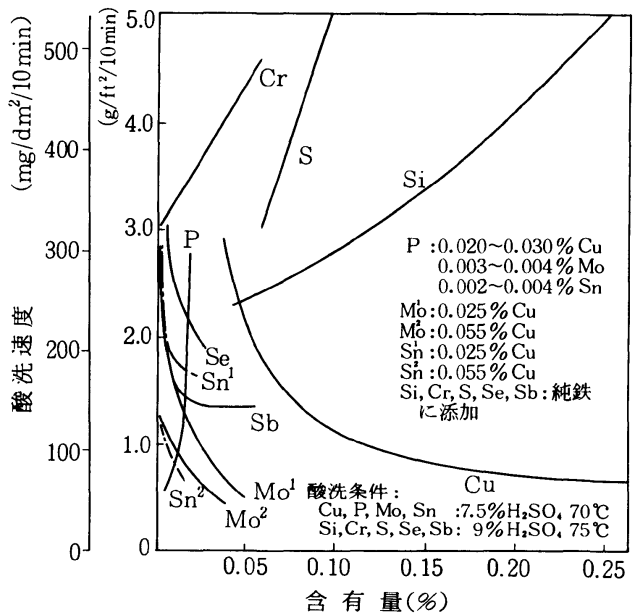

图 3 残留または添加元素含有量 (\%) と酸洗速度の関係 ${ }^{2)}$

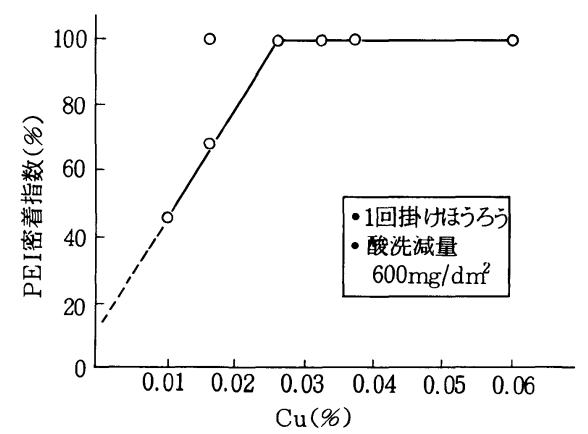

図 4 鋼中Cu含有量 (\%) とほうろう密着性の関係 ${ }^{11)}$

囲がかえって狭く不利益である場合あある1”。

次に，ほうろう密着性におよぼす鋼中微量元素の影響 について松藤 ${ }^{3)}$, 中川 ${ }^{9)}$, 蒲田 ${ }^{10)}$, 安田 ${ }^{5)}$ らの研究があ り, $\mathrm{Cu}, \mathrm{S}, \mathrm{P}, \mathrm{Ni}, \mathrm{Mn}, \mathrm{Cr}, \mathrm{Ti}$ などの元素について 検討している。てれらの元素の中では $\mathrm{Cu}$ 含有量がほう ろう密着性に最も大きい影響を与える。例えば, 図 $4{ }^{111}$ は酸洗減量 $600 \mathrm{mg} / \mathrm{dm}^{2}$ のときの 1 回掛けほうろうにお いて, $\mathrm{Cu}=0.017 \%$ 程度では不安定な密着性しか得ら れず, $\mathrm{Cu}=0.026 \%$ 以上になると安定した良好な密着 性が得られることを示している。

図 4 の中で密着性の程度を示す「P E I 密着指数」は 米国ほうろう協会 (PEI)の提案した方法で, 次のよう な手順で測定する。ほうろう掛けした試験片を直径 11 ンチの鋼球の下に置き, 2000 ポンドの一定圧力でプレ スして凹型の変形を与える。変形によりほうろうのはく 離した部分に Adherence Meterの169 本の針を接触さ せ，下地と短絡した針の数(n)を読み，（169-n/169） $\times 100$ で密着性を表示する。

一方，図 $5^{3)}$ で見ると，Cuが<0.004\%の場合であ酸 洗減量を過大にとれば密着性は得られるけれども，比較 


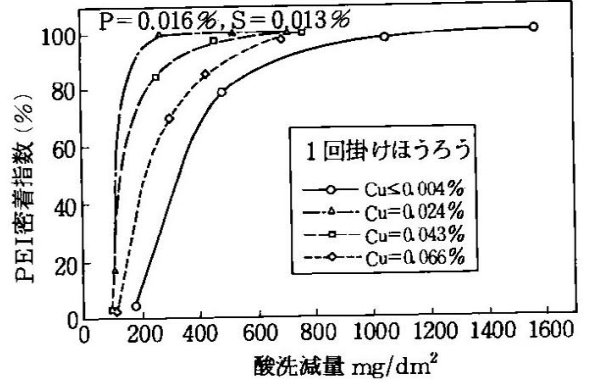

图 5 ほうろう密着性におよばすCu含有量の影響

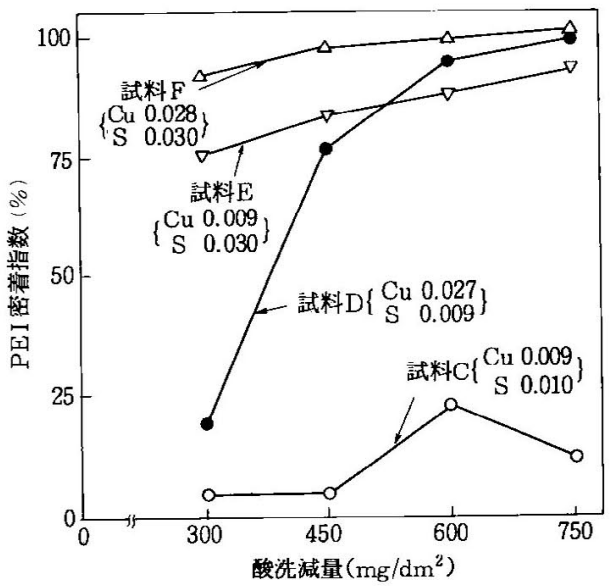

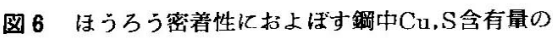
影製10) (1 回掛けほうろう)

的低酸洗減量域で良い密着性を得るための Cu範囲は 0.024 〜 $0.043 \%$ \%で。

また，蒲田ら ${ }^{100}$ は图6の結果から良好なほう万う密着 性を得るためには $\mathrm{Cu}$ ¿ $\mathrm{S}$ の共存が必要であり， Cu は $0.03 \%$ 程度以上，Sは $0.01 \%$ 程度以上が望ましいとし ている。

$\mathrm{Cu}$ または $\mathrm{Cu}+\mathrm{S}$ の作用機構についても多くの報告が

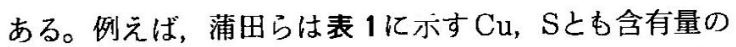
多い試料 $\mathrm{G}$ と $\mathrm{Cu}, \mathrm{S}$ とも含有量の少ない試料 $\mathrm{H}$ を選び酸
表 1 鎆枚表面挙動調查試料 10$\}$

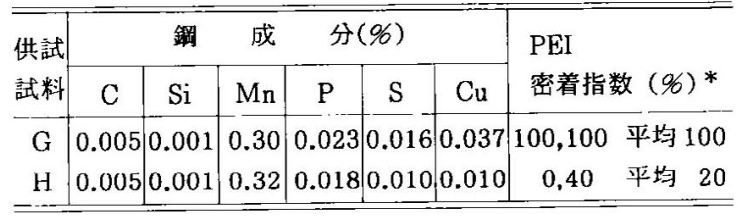

* 1 回挂けはうろう(酸洗減量 $500 \mathrm{mg} / \mathrm{dm}^{2}$ )

洗後および Ni 浸せき処理後の鋼板表面挙動を調べてい る ${ }^{10)}$ 。

図 7 は酸洗後の光学顕微鏡観察結果で, 密着性のよい 試料 Gの表面は黒いスマットに覆われているが不良な試 料Hは茶かっ色を示し，スマット量も少ない。

酸洗後鋼板表面に残留するスマットを E P A を用い て分析すると，酸洗前の鋼板表面に比べて C, Cuが比較 的強い感度で，また $\mathrm{S}, \mathrm{Si}, \mathrm{Ni}, \mathrm{Al}$ が弱い感度で検出さ れる。 $\mathrm{C}, \mathrm{Al}, \mathrm{Si}$ は硫酸酸洗溶液に溶けないカーバイト， アルミナ，シリケートとして残存し， $\mathrm{Cu}, \mathrm{Ni} は$ 金属状

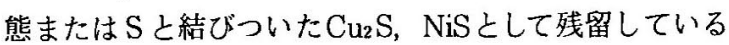
ものと考えられる。

図 8 は酸洗後の走査型電顕写真で, 試料Hには粒界に 深い孔食が見られるものの結晶粒内は比較的平たんであ るのに比べて試料 Gは粒内にも微細な粗れが観察される。 松藤らろう触針式粗度計では测定できないような粒内の 微細な粗れがほうろう密着性の機械的結合に寄与すると 指摘している。

$\mathrm{Cu}$ は鋼中で固溶しやすく，偏析しにくい元素といわ れ, $0.03 \%$ 前後の $\mathrm{Cu}$ は結晶粒内にも均一に分散されて おり鋼板が酸洗された場合，いったん溶解した $\mathrm{Cu}^{2+}$ は置 換反応により再析出するか，または $\mathrm{Cu}_{2} \mathrm{~S}$ のような化合 物之なって鋼板表面に沈積しスマットを形成する。生成 したスマットはポーラスな皮膜であり，また再析出した $\mathrm{Cu} \mathrm{Cu}_{2} \mathrm{~S}$ はカソードとなるため電気化学的禽食作用で 素地鋼板アノードを微細に，かつ急速に粗化させる㗢き をする。

これに比べて Cu含有量が少ない鋼板ではスマットの

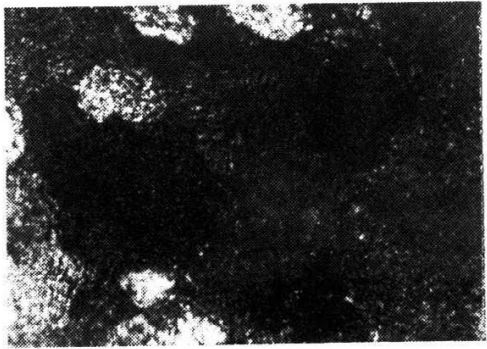

密着良好材 (試料 $G$ )

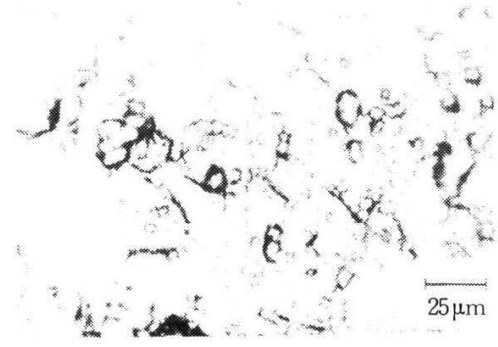

滰着不良材 (試料 $\mathrm{H}$ )

图 7 酸洗後鋼表面のスマット付着状況 ${ }^{10)}$

(酸洗減量 $500 \mathrm{mg} / \mathrm{dm}^{2}$ ) 


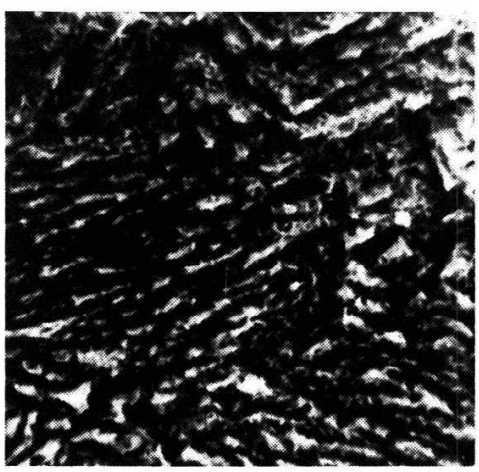

密着良好材(試料 G)

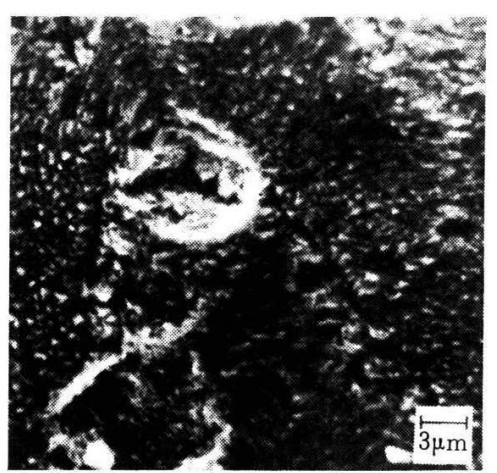

密着不良材 (試料 $\mathrm{H})$

図 8 酸洗後鍴表面の走査型電顕写真 ${ }^{10}$ ) (酸洗減量 $500 \mathrm{mg} / \mathrm{dm}^{2}$ )

生成量が少ないばかりでなく，不均一な皮膜となるため 粗化が進行せず，部分的に平たんな個所を生ずる。

スマットは酸洗に続いて行われる Ni 浸せき処理工程 においても重要な㗢きをする。図 9 亿示すように $\mathrm{Cu}$ 含 有量が<0.004\%の場合，Ni析出量が非常に少なくなる。 すなわち, $\mathrm{Ni}$ 浸せき処理は $\mathrm{Ni}^{2+}$ と $\mathrm{Fe}$ の置換反忍であっ て Feの溶解に伴って Ni が析出する。スマット量が少な く, 局部電池作用が弱い場合は置換反応以外に $\mathrm{H}_{2}$ 発生反

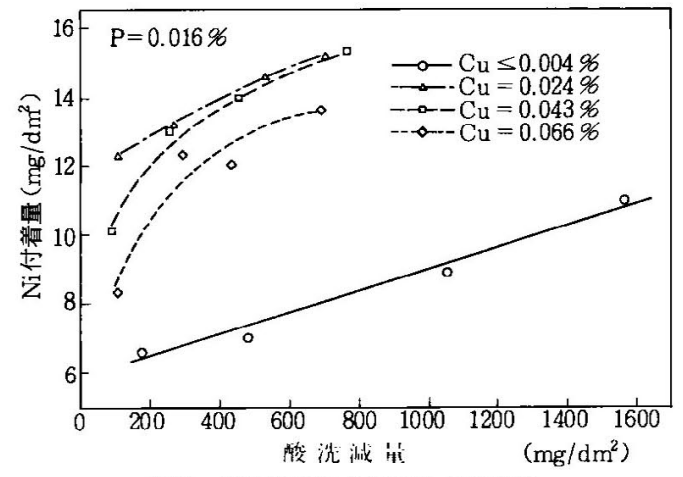

图 $9 \mathrm{Ni}$ 付着量に及ぼすCu量の影響

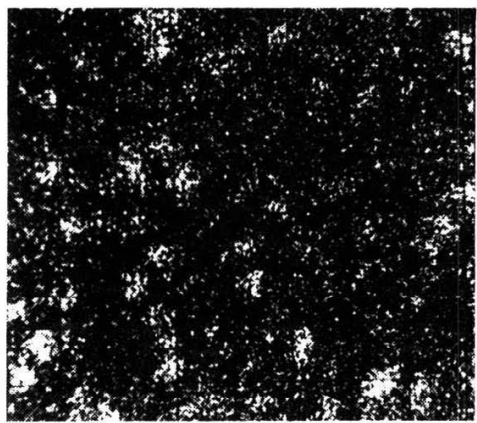

密着良好材(試料 $G$ )
応の方が起とりやすくなってNiの析出量が少なくなる。 また， $\mathrm{Cu}$ 含有量と $\mathrm{Ni}$ 析出状態の間にあ深いかかわり

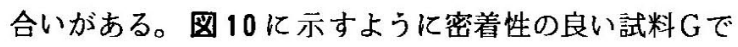
は，スマットが鋼板表面を均一に覆っているためカソー ド部分である $\mathrm{Cu}$ または $\mathrm{Cu}_{2} \mathrm{~S}$ 部分に均一，まばらに Ni が析出するが, 密着性不良である試料Hではスマット生 成が不均一なため $\mathrm{Ni}$ あ密に析出する部分(層状析出) と ほとんど析出しない部分が存在する。スマットが重要な 働きをするもうひとつの証拠は，酸洗後のスマットを強 制的に拭って除去した場合，図 $11^{91}$ 亿示すようにほう ろう密着性が極端に低下することである。

ほうろう密着性に扔よぼす $\mathrm{Cu}$ や 以外の元素の影㗽 は比較的小さい。Pは酸洗隇量速度を大きくし，表面を 粗化しやすいため間接的に密着性向上に効果があり, 含 有量は $0.010 \%$ 程度以上が望ましい3)。 Ni，Crは一般に ほうろう密着性に影響を与えないといわれるが, 中には スマット成分として残留し微力作用ながら $\mathrm{Cu}$ と似たよ うな㗢きをするという意見もある9”。Mn は含有量が多 くなると酸洗減量速度を増大させるが, 密着性にはほと んど影響を与えないとされる。しかしながら，松藤ら

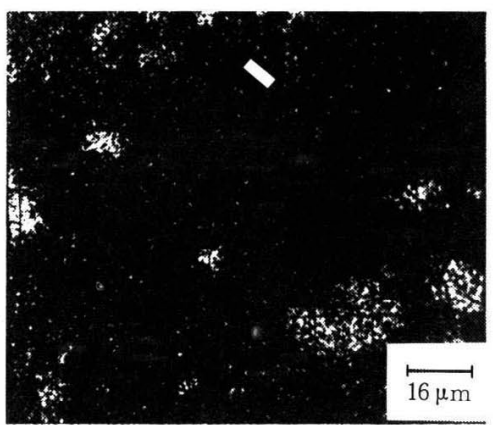

密着不良材(試料 $\mathrm{H})$

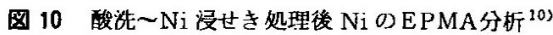

(酸洗娍量 $500 \mathrm{mg} / \mathrm{d} \mathrm{m}^{2}$ ) 


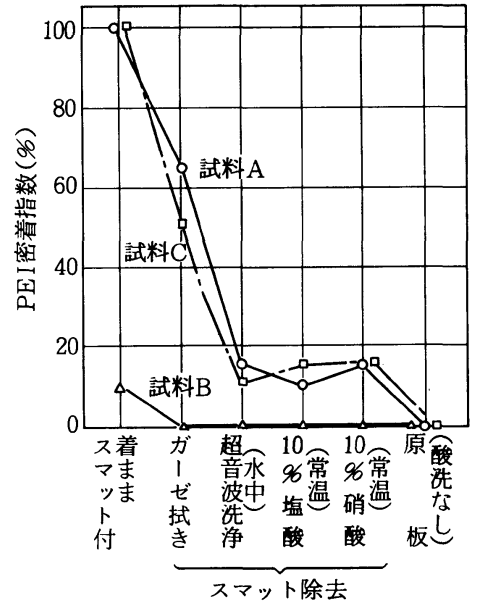

図 11 スマットを除去した場合のほうろう密着性 ${ }^{9)}$
A $\mathrm{Cu}: 0.09 \%, \mathrm{~S}: 0.030 \%$
B $\mathrm{Cu}: 0.02 \%, \mathrm{~S}: 0.008 \%$
C $\mathrm{Cu}: 0.03 \%, \mathrm{~S}: 0.019 \%$

は鋼板表面の $\mathrm{Mn}$ 量が多くなると焼成初期の $\mathrm{FeO}$ 生成を 阻害し，ほうろう層への $\mathrm{FeO}$ の融出を少なくするため化 学的結合力を低下させると述べている。しかし，乙れは 酸洗前処理なしで 2 回掛けほうろうを行う特殊な場合であ って, 酸洗を行う普通の場合表面 $\mathrm{Mn}$ は大部分溶出して しまうので Mnの影響はないあのと考えられる。

連続鋳造 $\mathrm{Ti}$ 添加鋼は, $\mathrm{Ti}=0.11 \%$ のとき酸洗減量が 多い領域でほうろう密着性が低下する傾向が見られ，そ の対策のためには $\mathrm{Ti}=0.06 \%$ 程度まで下げる必要があ る。 $\mathrm{Ti}=0.11 \%$ で密着不良を起とす理由は, スマットが 逆に多すぎる（ほうろう用リムド鋼板の 7 ～倍も生成 する）ためであることが明らかにされている5)。

\section{4. 鋼板前処理条件とほうろう密着性}

ほうろう製品の製造工程は図 12 亿示す通りで, $\mathrm{CoO}$ や $\mathrm{NiO}$ 含有する下ゆう薬を用いる 2 回掛けほうろうと 上ゆう薬を直接鋼板表面に被覆する 1 回掛けほうろうに 大別される。なお，2 回掛けほうろうにおいては, $\mathrm{Ni}$ 浸 せき処理を省略する場合あある。

鋼板に施ゆうされるゆう薬は，ゆう薬メーカーから供 給されるフリットに粘土, 電解質, 水などを加えて, ボ ールミルによって粉砕し泥浆状にしたあの（スリップと 呼ばれる）が用いられる。フリットは各種の原料を溶融 し，水中に流し込んで急冷して作られている。参考まで に下ゆう薬と上ゆう薬に用いられるフリットの化学成分 例を表 2 亿示す。

ほうろう密着性に対しては特に酸洗, Ni 浸せき処理, 下ゆう薬・上ゆう薬施ゆうおよび焼成工程が重要である。 酸洗処理は 3 章であ述べたように 1 回掛けおよび 2 回 掛けほうろうにとって不可欠のあのであり，鋼板表面の 酸洗液への溶解により生ずる粗面化およびスマットの生 成がほうろう密着性に有効な㗢きをしている。

従って, 酸の種類にも制限があり, 微細な粗化やスマ ットの生成が起こり難い塩酸酸洗は採用されず，むっぱ ら硫酸酸洗が使用される(硝酸酸洗の場合，ほうろう密着 性は良好であるが溶液の管理や廃水処理に問題があり，

一般には使用されていない)。

リムド鋼ほうろう用鋼板 $(\mathrm{Cu}=0.030 \%, \mathrm{P}=0.016 \%)$ の酸洗減量と 1 回掛けほうろう密着性の関係を図 13 11) に示している。

酸洗減量之 1 回掛けほうろう密着性の関係は前掲の図 5 にも示して抢り，乙れらの結果から良好なほうろう密

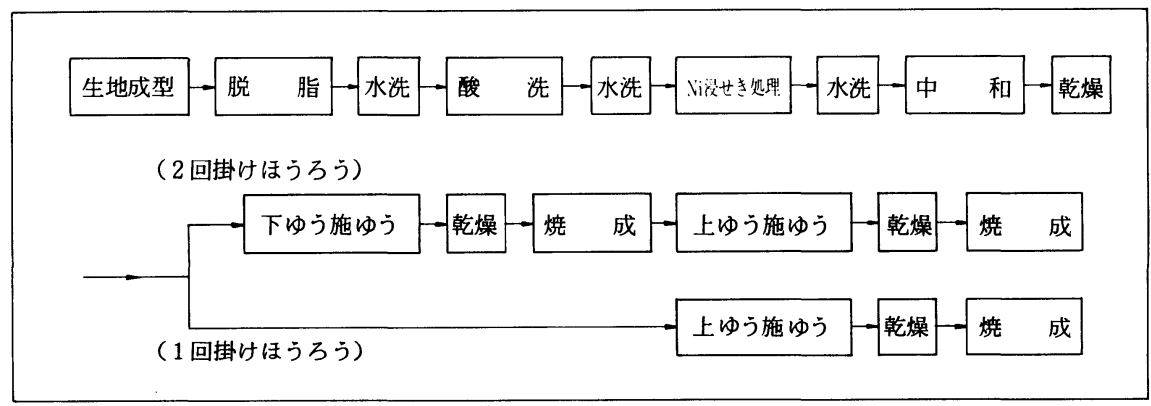

図 12 ほうろう製品の製造工程

表 2 フリットの化学成分例( wt \%)

\begin{tabular}{c|c|c|c|c|c|c|c|c|c|c|c}
\hline \hline & $\mathrm{Na}_{2} \mathrm{O}$ & $\mathrm{K}_{2} \mathrm{O}$ & $\mathrm{SiO}_{2}$ & $\mathrm{~B}_{2} \mathrm{O}_{3}$ & $\mathrm{MgO}$ & $\mathrm{ZnO}$ & $\mathrm{Al}_{2} \mathrm{O}_{3}$ & $\mathrm{CaF}_{2}$ & $\mathrm{Sb}_{2} \mathrm{O}_{3}$ & $\mathrm{TiO}_{2}$ & $\mathrm{CoO}$ \\
\hline トゆう楽フリット & \multicolumn{2}{|c|}{20} & 55 & 15 & - & - & 5 & 5 & - & - & $0.3 \sim 0.6$ \\
\hline トレウ楽フリット & 7.2 & 9.6 & 48.5 & 7.8 & 1.0 & 1.5 & 1.8 & 2.3 & 0.3 & 20.0 & - \\
\hline \hline
\end{tabular}




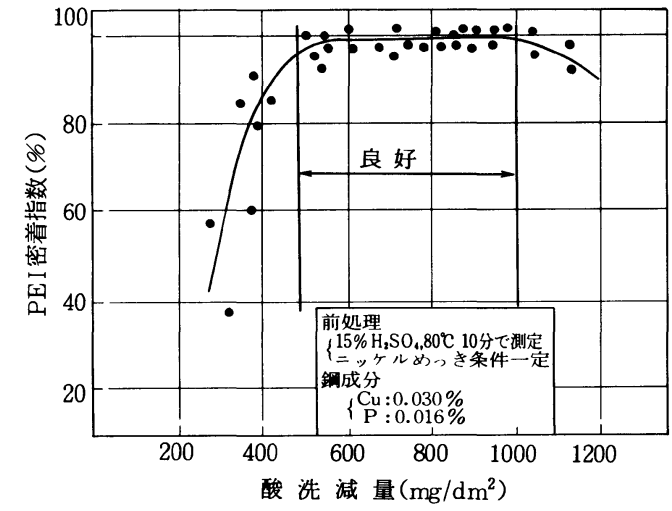

図 13 酸洗減量ट 1 回掛けほうろう密着性の関係 ${ }^{11)}$

着性が得られる酸洗減量は, 最低では $300 \mathrm{mg} / \mathrm{dm}^{2}$ であ るが，普通には $500 \mathrm{mg} / \mathrm{dm}^{2}$ 以上が必要である。また，

酸洗減量の上限は $1000 \mathrm{mg} / \mathrm{dm}^{2}$ 程度であり，それ以上 になるとスマット生成量が過剩となって逆に密着性が低 下する。酸洗減量が過大の場合，スマット中の成分であ るC化合物の蓄積量が多くなり泡も発生しやすくなる。 鋼板の酸洗減量速度は鋼中の $\mathrm{Cu}, \mathrm{P}, \mathrm{S}, \mathrm{Si}$ 濃度によって 変わりやすいことから、ロットごとに酸洗減量速度の事前 チェックが必要である。また, 酸洗浴の硫酸濃度や $\mathrm{Fe}^{2+}$ 濃度の定期的分析，温度の管理む重要である。

次に, Ni 浸せき処理条件之 1 回掛けほうろう密着性の 関係を図 14 亿示す。

図 14 を見ると， $\mathrm{Cu}=0.032 \%$ 鋼板の場合, 適正 $\mathrm{Ni}$ 付 着量は $8 \sim 40 \mathrm{mg} / \mathrm{dm}^{2}$ と広い幅であるが, $\mathrm{Cu}=0.016$ $\%$ の場合には $\mathrm{Ni}$ 付着量 $20 \sim 30 \mathrm{mg} / \mathrm{dm}^{2}$ の狭い幅でし
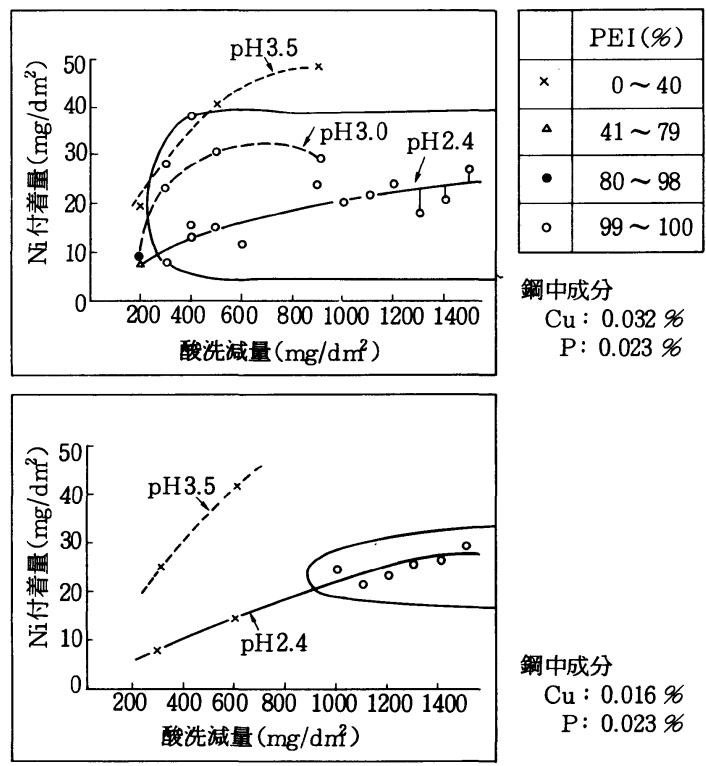

鋼中成分

$\mathrm{Cu}: 0.016 \%$

$\mathrm{P}: 0.023 \%$

图 $14 \mathrm{Ni}$ 浸せき処理条件と 1 回掛けほうろう密着性の関係 ${ }^{11}$
か良好な密着性は得られない。また, 図 14 は Ni浸せき 処理の $\mathrm{pH}$ 管理が大切であることを同時に示している。 $\mathrm{pH}$ は $2.4 \sim 3.6$ 程度が適正であり, $\mathrm{pH}$ が 3.5 と高くな ると $\mathrm{Ni}$ 付着量が過剩に析出し, 密着性を劣化させる。 てれは付着量が過剩になると, Ni はポーラスではなく層 状析出となり, 焼成過程での電気化学的腐食作用が起こ り難くなるためである。

$\mathrm{Ni}$ が過剩に析出した場合の密着性の劣化傾向は, 図 $15^{21}$ に示すように2 回掛けほうろうにおいてより顕著であり， $\mathrm{Ni}$ 付着量 $20 \mathrm{mg} / \mathrm{dm}^{2}$ 以上で急激に低下する。

2 回掛けほうろうの方が適正 $\mathrm{Ni}$ 付着範囲が狭い理由 は，下ゆう薬にCoOや $\mathrm{NiO}$ が含まれるためカソード部 の面積が増大し，焼成過程で充分な粗化が行われないた めである。乙れらの状況を示す鉄とほうろう層界面の顕 微鏡写真を図 $16^{111}$ 亿示しているが, $\mathrm{Ni}$ 付着量が過剩の 場合, 界面に $\mathrm{Fe}-\mathrm{Ni}$ 合金層が層状に存在し，その下の鉄 表面の粗化が不充分である様子がよくわかる。乙れに比 べて, 適正 Ni 付着量の場合には鉄表面の微細な粗れが 観察される。

その他， Ni 浸せき処理条件の中で浸せき浴中の $\mathrm{Fe}^{2+}$ 濃 度の影響がある。建浴直後の Ni 浸せき浴を使用すると pH 3 近傍でほうろう密着性が低下する傾向にあり，乙 の対策としてほうろうメーカーではスタート時に硫酸第 1 鉄を添加する方法を採用している。

$\mathrm{Ni}$ 浸せき浴中に $\mathrm{Fe}^{2+}$ を $6 \mathrm{~g} / \mathrm{L}$ 程度含むと $\mathrm{Ni}$ 析出速度 が抑制されるため, pH 2.0〜 4.0 の広い範囲で適正な付 着量が得られる。

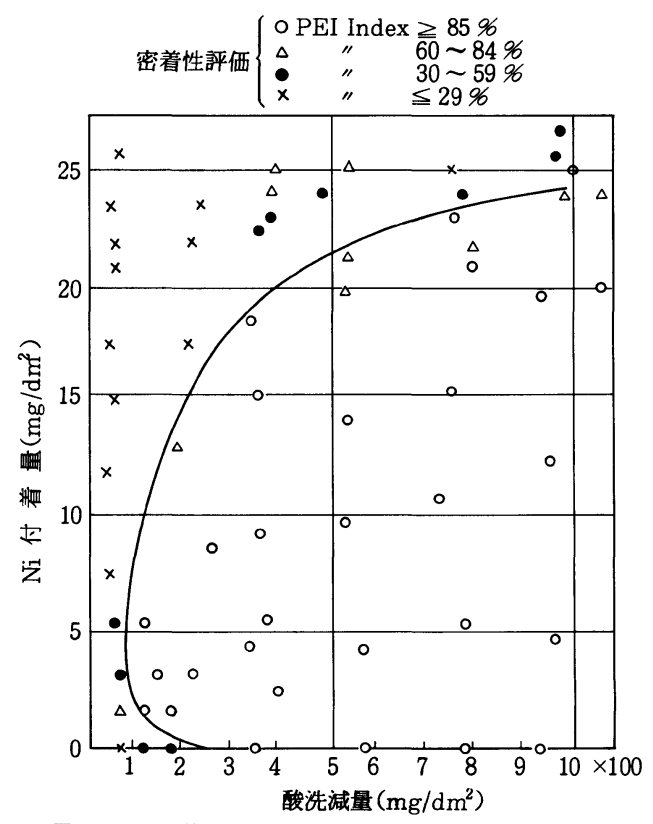

图 152 回掛けほうろうにおける前処理の酸洗減量 および $\mathrm{Ni}$ 付着量とほうろう密着性との関係 ${ }^{2)}$ 


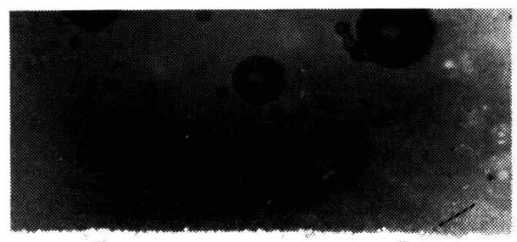

商正 $\mathrm{Ni}$ 付着量 $\left(\mathrm{Ni} 7 \mathrm{mg} / \mathrm{dm}^{2}\right)$

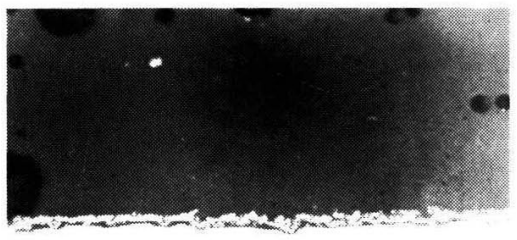

過剩 $\mathrm{Ni}$ 付着量 $\left(\mathrm{Ni} 23 \mathrm{mg} / \mathrm{dm}^{2}\right)$

図 $16 \mathrm{Ni}$ 付着量適正時と過剩時のほう万弓層界面の顕微鏡写真 ${ }^{11)}$ (2 回措けほうろう，酸洗減量 $200 \mathrm{mg} / \mathrm{dm}^{2}$ )

\section{5、Co-Mo合金めっきのほうろう密着性}

ほうろう密着性を得るための鋼板成分および前処理条 件について述べてきたが，鋼中の $\mathrm{Cu} ， \mathrm{~S}$ 成分含有量, 酸洗減量，Ni 付着量などを厳しく管理する必要があり， これらの量が不適当であると直ちにほうろう密着性に悪 影響をおよぼす。

そこでほうろうメーカーでの前処理を省略できる前処 理済み鋼板の考え方が生まれ，各種の方法が提案されて

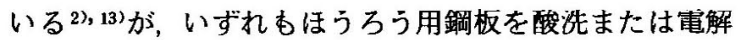
エッチングしたのち Ni 浸せき処理または $\mathrm{Ni}$ 電気めっき （低濃度浴を用い比較的高電流密度で電析させる）を行う 方法である。

蒲田らは更に一歩進めて鋼成分の制約がなく（脱炭は 必要），酸洗処理・Ni 浸せき処理を必要とせずに表面処 理皮膜のみで 1 回掛けほうろう密着性を得る方法につい て検討している ${ }^{14)}$ 。

その結果，鉄族金属( $\mathrm{Fe}, \mathrm{Co}, \mathrm{Ni})$ とMo または $\mathrm{W}$ と の合金めっきが比較的良好な密着性を示すことを明らか にし，中でも Co-Mo 合金めっきがほうろう性能および めっき性能の点から最も優れているとして詳しく検討し ている。

图 17 はCo-Mo 合金めっき付着量亡ほう万う密着性 の関係を示したもので，良好なほうろう密着性を得るた めには一定量以上の付着量が必要である。乙の最低付着 量は Co, Mo とあ約 $15 \mathrm{mg} / \mathrm{dm}^{2}$ である。

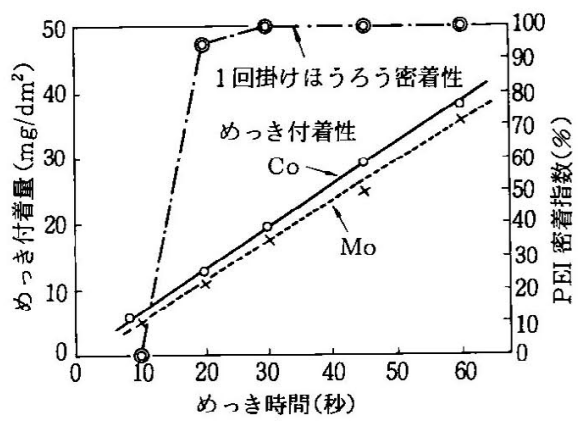

图 $17 \mathrm{Co}-\mathrm{Mo}$ 合金めっき付着量とほうろう密着性の関係 ${ }^{10}$
また, Co/Mo 合金比もほうろう密着性に深い関係が あり，図18から明らかなように良い密着性を得るため には Co/Mo 1.4 亿する必要がある。Co 含有量が多く なるとほうろう密着性は劣化する傾向を示す。

次に，Co-Mo 合金めっき鋼板にほうろう措けしたと きの密着機構を調べるために，ほうろう断面を顕微鏡で 観察すると，図19に示すようにめっき層に微細な亀裂 が認められ，素地鉄がはうろう層中に融解し，逆にほう ろう層がめっき層の下に入り込んでいるのが観察される。 このことから Co-Mo 合金めっき層(カソード)と $\mathrm{Fe}$ (ア ノード)との間で電気化学的腐食作用が生じ, かみ合い に基づく機械的結合が生まれているあのと考えられる。

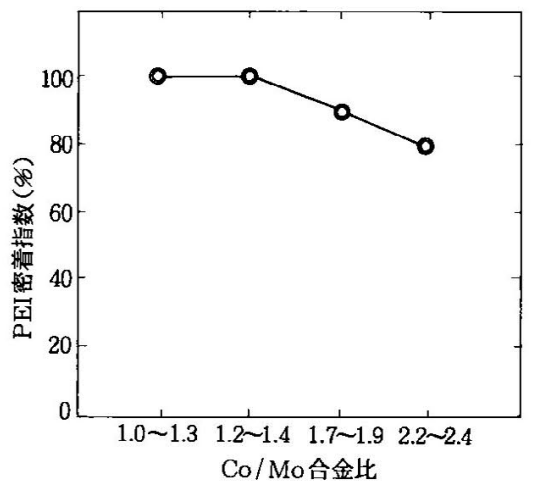

图 $18 \mathrm{Co} / \mathrm{Mo}$ 合金比率とほうろう密着性の関係 ${ }^{14}$ (1 回措けほう万う, Co $+M o$ 付着量 $30 \sim 40$ $\mathrm{mg} / \mathrm{dm}^{2}$ )

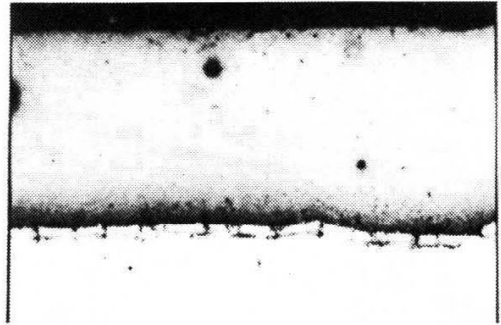

図 $19 \mathrm{Co}$-Mo 合金めっき $\rightarrow 1$ 回郝けはうろう 断面の顕微鏡写真 ${ }^{14}$ $\left(\begin{array}{l}\mathrm{Co}: 63 \mathrm{mg} / \mathrm{dm}^{2} \\ \mathrm{Mo}: 49 \mathrm{mg} / \mathrm{dm}^{2}\end{array}\right)$ 


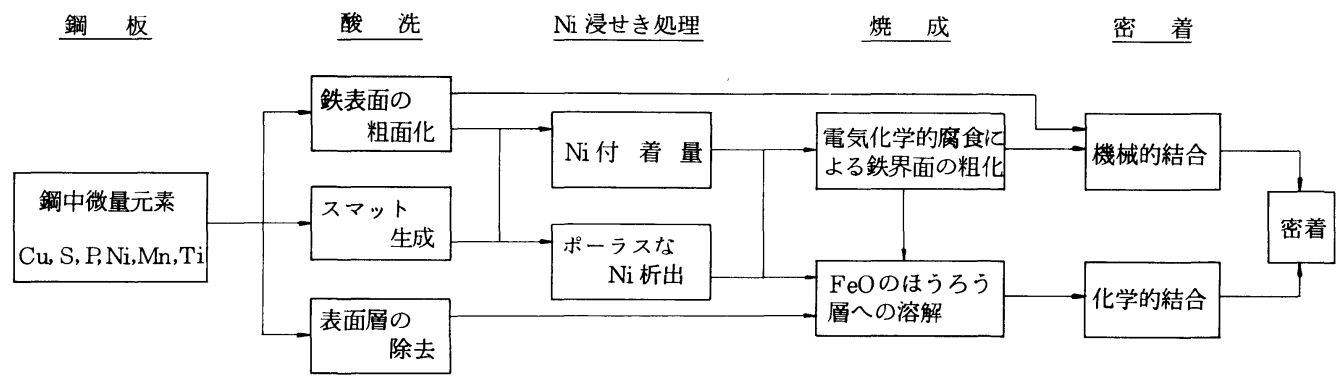

図 21 ほうろう密着要因の相互関係
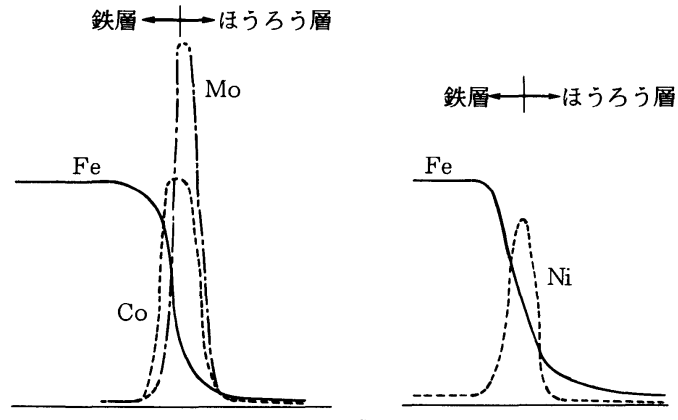

1 目盛 $\eta=1 \mu$

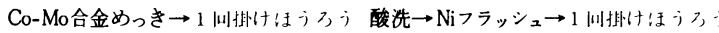

图 20 ほうろう断面の元素拡散状況 ${ }^{14)}$

一方，ほうろう層へのめっき金属の融解状況を見てみ ると，図 20 亿示すように Co-Mo 合金めっきの場合 $\mathrm{Ni}$ 浸せき処理に比べてほうろう層への Fe の融解は少ない が，Moは比較的多量に融解している様子がうかがえる。 このことおよび Co/Mo 合金比が小さいほど密着性がよ いととと考え合わせると, ほうろう層中へ $\mathrm{MoO}_{3}$ が融解 するととによって化学的結合あ生じているものと予想さ れる。

Co-Mo 合金めっき鋼板はほうろう密着性に優れ，か つ加工性もプレス加工に充分耐えられることからほうろ う前処理済み鋼板として使用可能であるが，コスト的な 問題から実用化までには至っていない。

近年, 耐熱性, 耐摩耗性, 耐食性を持たせるために二 ューセラミックスを金属表面にコーティングする方法が 注目されている。乙の場合セラミックスと金属との接合 技術がポイントであり，接合金属として上述したような $\mathrm{Co}-\mathrm{Mo}$ 合金めっきが使用される可能性む出てくるので はないかと予想される。

\section{6.あとがき}

鋼板，酸洗処理， $\mathrm{Ni}$ 浸せき処理分野におりるほうろう 密着性要因について述べたが, 密着要因の相互関係は図 21 のように整理することができる。

矢印は影響をおよぼす方向を示しており, 各々の密着 要因が伝播的にかかわり合いを持っている。
従って，ある分野のあるひとつの要因が不適当であっ ても良好なほうろう密着性は得難く, 各要因を厳密に管 理するととが肝要である。

現在，日本鉄鋼業におりる連鋳比率は $95 \%$ 以上に達し ており，ほうろう用鋼板あ造塊鋼(リムド鋼)から連続鋳 造鋼 (キルド鋼)に移行しつつある。

しかしながら，従来のほうろう密着性の研究はほとん に゙がリムド鋼板に関するあのであり，キルド鋼板につい ての検討は少ない。

キルド鋼板は $\mathrm{Al}$ を含有するばかりでなく，爪とび防 止のため $\mathrm{Ti}, \mathrm{S}$, 希土類元素( $\mathrm{La}, \mathrm{Ce}$ )などが添加されて おり, 今後元素の偏析状況, 表面粗化・スマット生成・ $\mathrm{Ni}$ 析出状態などについて基礎的な検討が必要であると 思われる。

\section{文献}

1）川北喜久治, 桜井 泰, 中村正也, 中道 弘; 大阪工業技 術試験所季報，22，〔4]，268(1971)

2）原田俊一；川崎製鉄技報，5，〔2〕，242（1973）

3）忪漛和脽, 下村隆良, 黒河照夫; 日本鋼管技報, [89], 155 (1981)

4) 松淡和雄, 井本文夫, 下村隆良, 黒河照夫; 害業協会誌, 91, [ 6 ], 273 (1983)

5 ）安田 顕; ）崎製鉄技報， 16, 〔4〕，280 (1984)

6 ) A. Dietzel ; Emailwaren - Ind., 11, 〔 19 ], 161 (1934)

7) B. W. King, etal ; J. Am. Ceram. Soc., 42, (11] 504 (1959)

8 ) J. A. Pask ; Univ. of California Radiation Laborato ry Report, 1061, (1), p.3 (1963)

9 ）中川洋一, 草䓡芳弘, 富田安夫; 日新製鋼技報, \{37\}, 51 (1977. 10)

10）蒲田 稔, 大沢正己，柴田政明，吉田 誠；鉄と鋼，70, (14), 1734 (1984)

11）新日鉄技術データより(未発表)

12）松滕和倠，下村隆良，黒河照夫; 日本鋼管技報，(67), 139 (1975)

13) Metal Finishing J., 13; [9], 298 (1967)

14）蒲田 稔, 吉田 誠, 兼近勝則, 山本二三夫 : 製鉄研究, [317], 80, (1985) 